ROCZNIKI TEOLOGICZNE

Tom LXVII, zeszyt $1-2020$

DOI: http://dx.doi.org/10.18290/rt20671-2

\title{
LILIIA KLOS
}

\section{THEORETICAL BASIS OF PRACTICE AND SOCIAL WORKERS PROFESSIONAL TRAINING FOR THE HEALTH CARE: RETROSPECTIVE REVIEW}

\begin{abstract}
Introduction. The international experience of social work in the field of health care shows that such activities of a social worker have a significant impact on the health of the population in the country and is necessary to improve the well-being of citizens.

Aim. The goal of the research was to study progressive foreign advanced theoretical developments concerning the training of social workers in the health-care for the implementation of such practices in Ukraine.

Material and methods. 53 units of scientific and scientific-practical sources of philosophical, psychological, pedagogical, medical content and problems of social work in the field of health were selected, systematized and analyzed. On the basis of comparison and synthesis of the received information, its generalization was made and presented in the form of conclusions

Results. The activities of social workers in the field of health-care are based on two main groups of theories - basic, found on the results of social work practices, and adopted from psychology, psychiatry, bioethics, nursing care, health care, sociology, administration.

Conclusions. In the practice of social workers in health care, health behavior theories (health belief model, theory of deliberate actions, planned behavior) and theories based on social networks (social behavior, behavior in the use of medical services), transtheoretical model are most often used. For the training of social workers in the field of health, both the basic and adopted theories are important; it is important in practice to be able to apply them in a comprehensive way, rely on eclectic knowledges in relation to the interdisciplinary nature of the activity.
\end{abstract}

Key words: social work; health care; theoretical basis; practice; social workers; professional training.

\section{INTRODUCTION}

Professional training of future social workers for health-care activities is scientifically and methodically grounded process of purposeful interaction of

Dr Lilita Klos, MD, D.Sc. in Education, Associate Professor, Department of Sociology \& Social Work, Institute of the Humanities and Social Sciences, Lviv Polytechnic National University, 4 Ye. Konovalec str., building 29, 79013, Lviv, Ukraine; e-mail: liliia.y.klos@1pnu.ua 
teachers and students in the formation of professionally competent future specialists, ready to creatively implement the relevant activities in the daily practice of social work, demonstrating samples of professional behavior. ${ }^{1}$ In the conditions of significant deterioration of the health of the population in Ukraine, the solution of the problem should be sought in an interdisciplinary approach and interprofessional cooperation of specialists. This is in line with current world trends in the industry and documents of the United Nations, the World Health Organization, the International Federation of Social Workers and the International Association of Schools of Social Work. Studying foreign experience of this kind of practice, as well as preparation for it, is important for domestic social work and the pedagogical branch.

The theory is a special field of human activity, representing a set of ideas, views, concepts, students, ideas about objective reality. This is a set of scientific knowledge that contributes to a holistic understanding of the laws and essential characteristics of objects. The theory of vocational training of social workers for activities in the health sector consists of two groups of concepts - basic (fundamental principles of learning) and derivatives (implications, conclusions). The assimilation of the theory occurs during practice - the activity of students, aimed at acquiring the relevant knowledge, skills, experience in social work for their further application in the professional field. ${ }^{2}$

The interdisciplinary nature of the activities of social workers is particularly clearly manifested in the field of health, which needs to be determined by the nature of social problems, taking into account the state of human health and the potential risks of its violation. This activity is based on a wide range of scientific theories and researches as their own theoretical resources and research results, as well as the theories of other humanities, including social pedagogy, anthropology, ecology, economics, education, administration, management, psychiatry, psychology, nursing care, health care, sociology and other specialized knowledge that contribute to attracting people and structures to solving vital problems and improving well-being. ${ }^{3}$

\footnotetext{
${ }^{1}$ World Summit on Social Development. (1995). Declaration and Programme of Action of the World Summit for Social development. URL: http://www.unesco.org/education/pdf/ COPENHAG.PDF, p. 65.

${ }^{2}$ S. GoncharenKo, Ukrainian Pedagogical Dictionary (Kyiv: "Lybid,” 1997), 327-328.

${ }^{3}$ Global definition of the social work profession (2014). URL: http://www.iassw-aiets.org/ uploads/file/20140303_IASSW\%20Website-SW\%20DEFINITION\%20approved\%20IASSW\%20 Board \%2021\% 20Jan\%202014.pdf. p. 1.
} 


\section{DESCRIPTION OF THE INVESTIGATION}

Given that social work in the health sector in Ukraine is fragmented, and the participation of social workers in addressing the health problems of the population is not sufficiently regulated and requires a clear definition of the roles, functions of the specialist and the limits of professional activities with the provision of social services in the context of conservation and health, it is expedient to study foreign progress in this area. Interest is the American experience of social work in the field of health, since in the United States, this trend in the activities of social workers has been actively developing for over a century (since 1903). ${ }^{4}$ In some universities of Ukraine, in particular in Lviv Polytechnic, training of social work specialists for health-preserving activities both in health care institutions and abroad is carried out. In this regard, particular interest is the understanding of the theoretical foundations of such activities and the appropriate training of social workers capable of solving social problems on the basis of health care. Therefore, the research questions, answers to which will give us the basis for a deeper understanding of the essence, the content of the practice of social workers in the health sector, are as follows. - Which of the well-known theories of social work are decisive in the training of social workers for health-caring activities? What knowledge are adopted from related industries required by social workers in solving social problems associated with violations of customer health?

In order to achieve the above goals, general scientific methods were used: analysis, synthesis, comparison, systematization, classification, generalization for the study of works of foreign and domestic scientists, official and normative documents, as well as comparative analysis of literature on philosophy, psychology, pedagogy, social work.

\section{MAIN RESULTS}

Change of the concept of social work at the turn of the nineteenth to twentieth century and the gradual transition from paternalism to humanistic views on social assistance contributed to the approval of the practical work of the medical model of social work which was grounded by M. Richmond. The main idea was to treat poverty or another problem of the individual as

\footnotetext{
${ }^{4}$ L.A. Cowles, Social Work in the Health Field. A Care Perspective (2nd ed.) (New YorkLondon-Oxford, 2003), 10.
} 
a disease, respectively, a person with a certain problem - as a "patient," who needs "social diagnosis" and "social treatment". A social worker should have correctly put a scientifically grounded social diagnosis and determine which method of intervention it was expedient to apply. The social diagnosis was based on the assessment of the client's personality and his social status, and the intervention involved measures for changing the environment and the person. ${ }^{5}$

The differentiation of influences associated with changing the social environment (indirect services) and directed to the individual (direct services), allowed to distinguish directions of the theory of social work. Thus, the theories of sociological and psychological orientation have been highlighted at the beginning of the twentieth century, and the diagnostic and functional schools of social work have been formed in the practical plane, which have substantiated and developed each of the directions. Theories of social work, focused on solving problems of individuals through changes in its social environment, received the name of the sociological direction (system theory, empirical, humanistic, environmental, social constructivism), but those aimed at transforming the individual himself were named the psychological direction (psychodynamic, behavioral, cognitive behavioral). Subsequently, the third direction - a complex intervention involving more modern theories (crisis intervention, feminism, problem-solving theory) - has been formed that allows solving social problems integrated.

The most important theories in healthcare social work are considered to be ecosystem (the theory of ecological perspective), "strengths" (the disclosure of internal potential) (Strength perspective), cultural competence. ${ }^{6}$ Ecosystem theory focuses on the interaction between a man and its environment. To understand the functioning of an individual, you must understand its environmental context, due to the situation of the person in the family, the situation of the family among the neighbors; the position of the person and family in a certain political, economic, cultural context; influence of its environment on actions, beliefs and personality choices.

The theory of "strengths" is based on the assumption that each person, family, group, community has certain advantages (resources), focusing on which increases the chances of overcoming difficulties. That is why clients,

\footnotetext{
${ }^{5}$ Ibidem, 15.

${ }^{6}$ J.A. DeBonis, The Role of Social Work in Integrated Health (California: California State University Northridge, 2013), 16; P. PANOS \& A. PANOS, "A model for culture-sensitive assessment of patients in health care settings," Social Work in Health Care (2000), 31(1): 49-62.
} 
as a rule, are the best experts in their own advantages and disadvantages, their effective and ineffective qualities; they are experts in their own lives. ${ }^{7}$ We agree with S. Rengasami's statement that there is no one ideal theory of social work for all cases and situations. This is what prompts a social worker to have constant and deep reflections, requires inquisitive intelligence, attentive, respect for the dignity of a client studying the complexity of social problems. F. Kerlinger believes that theory helps to select certain constructs that, when meeting social workers with clients, promote the use of conceptual ideas for understanding the client's problem and definition of the directions of the "production of the assistance process." 8

Knowledge of the theory of social work contributes to the "order" of any client situation or interaction between the client and the social worker, allows to compare situations in different contexts in practice, gives a general understanding of certain behavior patterns in the context of the situation; helps to combine research with practice in a common language to discuss clinical realities and anticipate their development for action planning. American scholars K. Glanz, B.K. Rimer, K. Viswanath conclude that a healthcare social worker without a theory "is similar to a technician," while a professional, armed with theory and research, is able to answer all the "Why do?" questions and capable to project and conclude an intervention plan successfully. ${ }^{9}$ Knowing that a certain action, is it hidden or explicit, is likely to lead to another action, allows intervention to promote behavior that will produce the desired results and reduce the likelihood of unwanted consequences. For example, it's known that people who understand the risk of developing a disease are more likely to participate in preventive behavioral practices, therefore we can focus on risk prevention in the development of measures.

The theoretical basis of a social worker's activities in health care has formed knowledge about human behavior and they require the use of appropriate skills by a social worker. Basing on the theories that helps to design

\footnotetext{
${ }^{7}$ S. Rengasamy, Social Case Work: Celebrating the dignity and worth of every individual (Compiled by S.Rengasamy Madurai Institute of Social Sciences, 2010), 28.

${ }^{8}$ S. Gehlert, T. Browne, Handbook of Health Social Work (2nd ed.) (New Jersey: John Wiley \& Son, 2012), 126; F.N. KerLinger, Foundations of behavioral research (New York, NY: Holt, Rinehart and Winston, 1986), 10.

${ }^{9}$ S. Rengasamy, Social Case Work: Celebrating the dignity and worth of every individual (Compiled by S. Rengasamy Madurai Institute of Social Sciences, 2010), 126; K. GLANZ, B.K. RIMER \& K. ViswanATh, "Theory, research, and practice in health education," in K. GlanZ, B.K. Rimer $\&$ K. ViswanAth (Eds.), Health behavior and health education: Theory research and practice (pp. 21-40) (San Francisco, CA: Jossey-Bass, 2008), 23-24.
} 
professional intervention, social workers increase the likelihood of successful outcomes.

Health-saving activities of a social worker, in addition to the key theories of social work, are based on the use of such theories and models: behavior (J. Skinner, I. Pavlov); crises (K. Ell, B. Gilliland, R. James, H. Parade); ecological system (L. von Bertalanfi); life cycle of the family; empowerment (empathy) (E. Cox, L. Gutierrez, D. Lee, E. Canada, P. Chatterjee, V. Robbins); cognitive (A. Adler, J. Piaget), psychodynamic (Z. Freud, E. Erickson) and humanistic (existential/transpersonal) theories (A. Maslow, K. Rogers, C. Jung); socio-cultural (L. Vygotsky, T. Sheff) and object relations (M. Maler, O. Kernberg) theory; therapy focused on solving the problem (M. Bowen, V. Satire) and strategic therapy of the family system. ${ }^{10}$

\section{DISCUSSION}

Psychoanalytic theory (Z. Freud) and "ego-psychology" (H. Hartmann, E. Erickson); psychosocial therapy (M. Richmond, G. Hamilton, A. Garrett), sociological theory of problem solving (H. Perlman, B. Betz); ${ }^{11}$ functional theories (G.Mead, J. Dewey, O. Rank); client-centered therapy ("therapy of relationships," group therapy and person-centered psychotherapy K. Rogers), therapy of reproduction (V. Exclaian), cognitive theory (rational psychotherapy, cognitive therapy G. Weiner, A. Adler) are widely used for diagnostics and clinical social work in healthcare. Among the theories of social interaction, healthcare social work uses the theory of gestalt (F. Perls, L. Perls, P. Goodman), roles (R. Benedict, C. Davis), as well as therapy for modification of behavior ("therapy of action") (B. Skinner), family therapy.

According to $\mathrm{S}$. Rengasami each theory is an attempt to explain the retrospective and predict a perspective. Theories of the functional direction are formed under the influence of the philosophy of G. Mead, J. Dewey, O. Rank. Thus, the therapeutic theory provides an understanding of the terminology of therapeutic work of a social worker. It replaces the term "therapy" by "service," the client is perceived not as a passive patient but as an active agent

${ }^{10}$ H.P.A Van De Water, H.C. Boshuizen \& R.J.M. Perenboom, "Health expectancy in the Netherlands 1983-1990," European Journal of Public Health (1996), 6: 21-28; S. RENGASAMY, The puls of Social Work: Theories of Social Work (Alagar Koil Road: Madurai Institute of Social Work, 2015).

${ }^{11}$ H.H. Perlman, Social casework: A problem-solving process (Chicago, IL: University of Chicago Press, 1957). 
that develops as a result of using the functions of a specialist and receiving services from the agency. ${ }^{12}$

Client-centered therapy (therapy of relationships, therapy focused on the group, client-oriented therapy of K. Rogers, V. Exclaian) defines personal counseling and psychotherapy as the main components of influence of nondirect psychiatry, based on recent clinical psychology research. Mental health social workers use these methods as means of perception and preservation of an integral person, they help in the work of groups to overcome family maladaptation as well as in teaching and learning, not related to therapeutic interventions. ${ }^{13}$

The cognitive theory (cognitive technique by G. Weiner, A. Adler) covers "rational," "realistic" or "phenomenological" approaches as socially oriented, based on the belief that emotions, motives, behavior, and thinking depend on the influence of society, the immediate social environment, human relations and experience that rejects the elements of the unconscious in psychology. Cognitive theories that focus on reality can serve as guidance for all forms of therapy : individuals, groups and communities.

The theory of sociological orientation in social work - Gestalt theory (F. Perls, L. Perls, P. Goodman) is formed under the influence of psychoanalysis, existential philosophy (V. Reich). To analyze the situation of the client, Gestalt psychology uses the elements of Eastern religions, concentrated in Gestalt therapy, and conscious contact with the environment, it directs the social worker to encourage the full expression of the client in the context of psychological needs. Gestalt therapy, based on the philosophy of phenomenology and existentialism, offers greater opportunities for therapeutic social work with a personality - a clinical social work based on a method of work with a case (case-study). Some researchers argue that the organic nature of the Gestalt theory and the close relationship with the theory of systems allows it to be used for both macro and microsystems, in group work and in work with community. ${ }^{14}$

The theory of case work involves more than 50 variants of individual case management, most of which focus on explaining behavior, not behavior changing procedures, and are based on the psychodynamic theory ( $Z$. Freud, psychoanalysis) and ego psychology. ${ }^{15}$ Main components of case work are

\footnotetext{
${ }^{12}$ S. Rengasamy, The puls of Social Work: Theories of Social Work, 12-16.

${ }^{13}$ Ibidem, 14.

${ }^{14}$ Ibidem, 15.

15 S. MCLEOD (2008), Case Study method. URL: http://www. simplypsychology. org/casestudy.html.
} 
"man-problem-place-workflow" focused on customer relationship and problem solving. The two most commonly used approaches to dealing with a specific case are: focusing on the problem (deficit) and the approach of "strengths," which are particularly relevant in the context of health care activities. Comparison of approaches gives a clear understanding of the advantages of the theory of development of internal potential, the key of which is the perception and evaluation of a person and his health in a holistic way (from the point of view of holism), which promotes active participation of the client in changing the situation for the better, based on clints' special features, talents as assets (resources), personal responsibility for everything that happens in its life, in interaction with a social worker and with the support of environment (community). ${ }^{16}$

With the help of ego psychological approaches one can see the "broader psychological horizons" in dealing the case: the theory of the protection mechanism (Z. Freud), stages of psychosocial development (E. Erickson), the therapy focused on the client (C. Rogers) and cognitive therapy are based on common principles and assumptions. In particular, they include: 1) people of all ages have an opportunity to develop, learn, adapt and to some extent change their social and physical environment; 2) psychological systems are not isolated, they constantly interact with biological and social systems; 3 ) the behavior of people develops in the context of many open systems, interacting in mutually causal relationships; the change of one system inevitably leads to a change in other systems; 4) the family system provides the most meaningful context of personal growth and development; the problems of matching between family members are reciprocal; 5) families suffer from stress caused by larger systems such as poverty, racism, illness, etc.; the daily lives of many clients are influenced by these systems.

In practice of healthcare professionals often turn to the following theories of a separate case: a) cognitive (social cognitive theory); b) social roles (theory of role perspective); c) modification of behavior. The theory of behavior modification is used to demonstrate change in behavior using empirical methods; something like operant training (in the absence of a particular antecedent). Modification of behavior or "applied behavior analysis" is more analytical than applied. ${ }^{17}$

\footnotetext{
${ }^{16}$ H.P.A. VAn De Water, H.C. Boshuizen \& R.J.M. Perenboom, "Health expectancy in the Netherlands 1983-1990," 23.

${ }^{17}$ S. Rengasamy, The puls of Social Work: Theories of Social Work, 36.
} 
Theories of behavior are most demanded in the practice of health-saving activities of a social worker. The most relevant are: 1) the theory of learning outcomes (I. Pavlov) or "classical conditioning," based on the formula "stimulus-response" (S-R); 2) the theory of operant enrichment (B. Skinner), on the basis of "classical learning" in conjunction with the idea of the inherent activity of people in the learning process, rather than the classical; active participation of a person is important for training. In the case of encouragement the behavior remains and it is supported, and in the case of punishment the behavior disappears; 3 ) the theory of social modeling (learning) is based on A. Bandura's ideas about learning as a result of copying or imitating what others do, that is, substitute learning.

The theory of social modeling emphasizes the importance of external reinforcements, enables learning to be realized independently of external circumstances. The basic principles of behavior change in social modeling: a) human behavior is determined by learning and it can be managed taking into account the regularities of teaching (educational process); b) human behavior is the result of training and the person is responsible for its violation or correction; c) the behavior of a person depends on the consequences: it is strengthened when obtaining awards and worsens (or collapses) with negative consequences; d) human behavior is determined not only by internal factors but also by external factors, such as the presence of meaningful role models and other social incentives (praise or rewards); e) inappropriate behavior can be changed by changing the circumstances that support it; f) human beings begin life "from a blank sheet of paper"; "inheritance" of good or bad habits begins when people come into the world; g) the behavior is "assimilated" individually by observing others, training or conditioning; h) people who learn to change negative behavior need to be supported in their efforts by monitoring positive behaviors. ${ }^{18}$ Modifications of behavior use the principles of effective learning that affects behavior. The social worker's application of the rules of behavioral modification makes it possible to promote an effective change in the mental health of the client by solving cognitive or emotional problems. This is especially important in working with patients from treatment and diagnostic institutions and other institutions when it is necessary to change behavior. ${ }^{19}$

\footnotetext{
${ }^{18}$ Ibidem, 37.

19 R.V. Luepker, C.L. Perry, S.M. McKinlay, P.R. Nader, G.S. Parcel, E.J. Stone, L.S. WebBer, M. Wu, “Outcomes of a Trial to Improve Children's Dietary Patterns and Physical Activity: The Child and Adolescent Trial for Cardiovascular Health (CATCH)," Journal of the American Medical Association (1996), 275: 768-776; J. Smetana \& M. AdLER, "Understanding
} 
Knowledge of the theory of attribution (L. Abramson, M. Seligman, J. Teasdale) allows to predict depression in people which attribute negative events in their lives to their own activities, it helps in understanding the links between the structures of control of power and psychosocial problems. ${ }^{20}$ The theory of attribution explains the reasons why people in contact with a world, in which they have little control, attempt to impose this control, for example, in a disease situation that they are not able to control. L. Abramson and others proposed three dimensions of causal attribution: 1) internality and externality (search for a cause in a person or other persons, circumstances); 2) globality and specificity (the same explanations can be used for a multitude of facts or as specific to one or more facts); 3) stability and instability (refers to the duration of the effect of the cause - long or temporary). ${ }^{21}$ To diagnose the level of attribution, a social worker uses an attribute style questionnaire or a content analysis of the verbal explanation of health behavior. ${ }^{22}$

Among the theoretical approaches on the basis of a rational choice for social work in the field of health, relevant are health behavior theories that explain the behavior of human rational, logical mental processes. The choice of people for the benefit of health is largely based on the cost considerations and the benefits of various actions. Basic versions of theories of rational behavior in health are the model of beliefs about health and the theory of reasonable actions, as well as the theory of planned behavior (I. Ajzen, T. Madden). ${ }^{23}$

A model of health beliefs, proposed in the 1950s to explain human behavior in connection with screening for tuberculosis, is based on understanding of the behavior of individuals as a determinant of health. In the 1970s-80s. the emphasis mainly on this factor has led to a decrease in attention to a much wider range of social determinants of health, it focused on medical education and the behavior of people instead. ${ }^{24}$ Authors of the model of health beliefs

the abortion decision: A test of Fishbein's value expectancy model," Journal of Population (1986), 2: 338-357.

${ }^{20}$ L.Y. Abramson, M.E.P. Seligman \& J.D. Teasdale, "Learned helplessness in humans: Critique and reformulation," Journal of Abnormal Psychology (1978), 87: 49-74 (p. 52).

${ }^{21}$ Ibidem, 59.

${ }^{22}$ C. Peterson, B.A. BetTes \& M.E.P. Seligman, "Depressive symptoms and unprompted causal attributions: Content analysis," Behaviour Research and Therapy (1985), 23: 379-382 (p. 380).

${ }^{23}$ I. AJZEN, "The theory of planned behavior," Organizational Behavior and Human Decision Processes (1991), 50: 179-211. I. AJZEN \& T.J. MADDEN, "Prediction of goaloriented behavior: Attitudes, intentions, and perceived behavioral control," Journal of Experimental Social Psychology (1986) 22: 453-474.

${ }^{24}$ G. Hochbaum, Public Participation in Medical Screening Programs: A Sociopsychological Study (Washington: Public Health Service Publication, 1958), 36. K. GlanZ, B.K. Rimer \& 
John. Hoshbaum and A. Rozenstock explained the non-participation of people in screening for tuberculosis, despite the presence of mobile vans for fluorographic survey in their vicinity, the two main components of health behavior - the threat and expected results. ${ }^{25}$ The threat includes the predicted propensity to poor health and the predicted severity of the condition. For example, in the case of the risk of AIDS, the "threat" component will lead to the same understanding of the risk of infection by a person who is prone to HIV infection, as represented by the medical community, and will act accordingly. The "expected result" implies giving preference to certain actions, such as the use of protective measures to prevent the transmission of HIV and predicting barriers to this action.

The benefit of measures to reduce the risk of contracting HIV infection may be to stay alive, while the barrier may be the purchase price of a remedy or the fear that the offer will be rejected after the sexual partner has informed the expediency of using the means of protection against transmission of infection. ${ }^{26}$

The model of health beliefs is also recognized as effective in social work with outpatient psychiatric patients to support the drug regimen (G. Kelly, J. Mamont, J. Scott) ${ }^{27}$ with influenza vaccination for those at high risk for lifethreatening complications from the disease (E. Larson, J. Bergman, F. Heydrich, B. Alvin, R. Schneeweiss), ${ }^{28} \mathrm{n}$ the screening of women's behavior regarding breast cancer and cervical cancer $(\mathrm{K}$. Ingledue, R. Cottrell, A. Bernard, E. Tanner-Smith, T. Brown, ${ }^{29}$ in attracting mothers with a low socio-economic

K. ViSWANATH, "Theory, research, and practice in health education," in K. GLANZ, B.K. Rimer \& K. VISWANATH (Eds.), Health behavior and health education: Theory research and practice (pp. 21-40) (San Francisco, CA: Jossey-Bass, 2008); D.S. Gochman, Handbook of Health Behavior Research, I: Personal and Social Determinants (New York: Plenum Press, 1997), 23.

${ }^{25}$ I.M. Rosenstock, "What research in motivation suggests for public health," American Journal of Public Health (1960), 50: 295-301 (p. 297); I.M. RosENSTOCK, "Historical origins of the health belief model.Health Education Monographs" (1974), 2: 328-335; G. HochBAuM, Public Participation in Medical Screening Programs, 15.

${ }^{26}$ S. Gehlert, T. Browne, Handbook of Health Social Work (2nd ed.) (New Jersey: John Wiley \& Son, 2012), 128-129.

${ }^{27}$ G.R. Kelly, J.A. MAMON \& J.E. ScOtT, "Utility of the health belief model in examining medication compliance among psychiatric outpatients," Social Science and Medicine (1987), 11: 1205-1211 (p. 1207).

${ }^{28}$ E.B. Larson, J. Bergman, F. Heidrich, B.L. Alvin \& R. Schneeweiss, "Do postcard reminders improve influenza vaccination compliance?" Medical Care (1982), 20: 639-648 (p. 642).

${ }^{29}$ K. Ingledue, R. Cottrell \& A. Bernard, "College women's knowledge, perceptions, and preventive behaviors regarding human papillomavirus infection and cervical cancer," American Journal of Health Studies (2004), 19: 28-34 (p. 31); E.E. TANNER-Smith, T.N. Brown, 
status to adhere to the schemes for reducing the body weight of their children affected by obesity (M. Becker, L. Maiman, J. Kirscht, D. Haefner, R. Drachman) and other. Empirical data confirm the validity of the model of belief in health forecasting results. ${ }^{30}$

It was found that among the alleged threats the ones that reflect the earliest manifestations of the disease are perceived the most, and the predicted propensity and expected benefit - as an intermediate. This made it possible to assume that certain fears of a person are perceived as obstacles to behavioral changes to a healthy person (no difference are they real or imagined). ${ }^{31}$ For example, the fear of hair loss from radiation therapy is much greater than other factors, such as the severity of the disease, predisposition to illness, etc. That is what determines the benefits of a person's decision in choosing behavior. It turned out that the perception of the severity of a disease is the least significant factor in determining health behavior in the case of cancer. ${ }^{32}$

The theory of weighted actions (M. Fishbein, I. Ajzen) has expanded the range of problems to which the model of beliefs concerning health is applied, since it involves taking into account the influence of significant others in the environment of the individual on his behavior in relation to health. ${ }^{33}$ According to this theory, behavior is determined by behavioral intentions. Behavioral intent, in turn, is determined by the attitude of a person to the behavior of significant others in the environment, that is, the social norm. Attitude to behavior consists of two aspects: the beliefs of the individual that the behavior contributes to the improvement of the result; the result will depend on its significance for the individual. The social norm contains the belief that meaningful others will think about the performance of the individual in conjunction with the individual's motivation to listen to someone else's thought. For example, a social worker should remember the perception of

"Evaluating the health belief model: A critical review of studies predicting mammographic and pap screening," Social Theory \& Health (2010), 8(1): 95-125 (p. 117).

${ }^{30}$ M.H. Becker, L.A. Maiman, J.P. Kirscht, D.P. Haefner \& R.H. Drachman, "The health belief model and prediction of dietary compliance: A fi eld experiment," Journal of Health and Social Behavior (1977), 18: 348-366.

${ }^{31}$ N. JANZ, M. BECKER, "The health belief model: A decade later," Health Education Quarterly (1984), 11: 1-47 (p. 22).

32 Right there, p. 31.

${ }^{33}$ M. FishbeIN, "Attitude and the prediction of behavior," in M. FishbeIN (Ed.), Readings in attitude theory and measurement (pp. 477-492) (New York, NY: Wiley, 1967); M. FishBeIN, I. AJZEN, Belief, attitude, intention, and behavior: An introduction to theory and research (Reading, MA: Addison-Wesley, 1975). 
a young woman what her friend, closest friend, mother and doctor will think about her decision to abort, and her motivation to listen to their thoughts in an attempt to understand or predict her behavior.

The theory of weighted actions has been applied to many types of behavior and in various conditions of health, particularly in situations of abuse of psychoactive substances, in patients with hypertension and in situations of combat overweight (D. Sejwacz, I. Ajzen, M. Fishbein). ${ }^{34}$ Since those who have an impact on the individual are taken into account, the theory of deliberate action is widely used in the correction of behavior in adolescents' health, in particular in making decisions about the use of contraception (by D. Albarracin, B. Johnson, M. Fishbein, P. Muellerleile,), ${ }^{35}$ abortion (according to J. See Tan, M. Adler), ${ }^{36}$ risky sexual behavior (by J. Dzhemmot, L. Dzhemmot, G. Fong). ${ }^{37}$

The theory of planned behavior (I. Ajzen, T. Madden) has become widespread in connection with the theory of deliberate actions in order to include the aspect of predictable control over behavior. The basic idea is that only the intentions themselves can not predict behavior, if the behavior of the individual was not completely controlled. ${ }^{38}$ The control of the predicted behavior is a reflection of a previous problem faced by a person. That is, if the client had unsuccessful attempts to change behavior to solve such a problem as weight loss in the past and poor control of behavior was demonstrated, the likelihood that the same client will be able to maintain behavior, regardless of how strong his intentions are, decreases. The theory of planned behavior is used to predict the behavior of different clients: in connection with the nurse's appointment of opiates for pain relief (H. Edwards, R.E. Nash,

${ }^{34}$ D. SEJWACZ, I. AJzen \& M. Fishbein, "Predicting and understanding weight loss," in I. AJZEN \& M. FISHBEIN (Eds.), Understanding attitudes and predicting behavior (pp. 102-112) (Englewood Cliffs, NJ: Prentice-Hall, 1980).

${ }^{35}$ D. Albarracín, B.T. Johnson, M. Fishbein \& P.A. Muellerleile, "Theories of reasoned action and planned behavior as models of condom use: A meta-analysis," Psychological Bulletin (2001), 127: 142-161.

36 J. SMETANA \& M. ADLER, "Understanding the abortion decision: A test of Fishbein's value expectancy model," Journal of Population (1986), 2: 338-357.

${ }^{37}$ J.B., III Jеммотт, L.S. Jеммотт \& G.T. FonG, "Reductions in HIV risk-associated sexual behaviors among Black male adolescents: Effects of an AIDS prevention intervention," American Journal of Public Health (1992), 82: 372-377.

${ }^{38}$ I. AJZEN \& T.J. MADDEN, "Prediction of goaloriented behavior: Attitudes, intentions, and perceived behavioral control," Journal of Experimental Social Psychology (1986), 22: 453-474 (p. 457). 
J.M. Najman, P.M. Yates, B.J. Fentiman, A. Dewar, H. Skerman), ${ }^{39}$ in screening for cervical cancer, in work with aggressive (fierce) adolescents (J. Gemmott, L. Gemmott, P. Hines, G. Fong).$^{40}$ It is suitable for use by clients whose behavior requires more voluntary control and for people with negative past behavioral control experience in the past, for example, controlling the behavior of weight loss, when higher results were obtained from clients for which combinations of prediction models and predictive behavioral controls were applied, than those who only considered intentions. To support long-term health improvement initiatives, the theory of organizational change is used, for example, to encourage the adoption of comprehensive school smoking control programs. The application of the theory of innovation and the theory of intelligent action was effective in analyzing the factors associated with the adoption of AIDS prevention programs in Dutch schools and proved their effectiveness. ${ }^{41}$

Theoretical approaches, based on social networks, were formed on the background of critical thinking about rational choice of approach. It has been determined that such an option will not be adequate if one does not take into account the environmental impact of behavior. The approaches based on social networks shift the emphasis from the mental activity of individuals to social relations, recognize the social nature of people. Conceptualized decisions taken by individuals about health are the main (axis) in developing an intervention plan, and social-based approaches complement them. Social networks constitute an intermediate link between the axial and "external" components represented by a wider social system that encompasses the existing socio-economic reality. The approaches used in this model are reflected in the theory of social action and in the behavioral model of the use of medical services. ${ }^{42}$

39 H.E. Edwards, R.E. Nash, J.M. Najman, P.M. Yates, B.J. Fentiman, A. Dewar, H.M. SKERMAN, "Determinants of nurses' intention to administer opioids for pain relief," Nursing Health Science (2001), 3: 149-159.

${ }^{40}$ J.B., III Jemmott, L.S. Jemmott, P.M. Hines \& G.T. Fong, "The theory of planned behavior as a model of intentions for fighting among African American and Latino adolescents," Journal of Maternal and Child Health (2001), 5: 253-263 (p. 257).

${ }^{41}$ A. Franks, S.H. Kelder, G.A. Dino, K.A. Horn, S.L. Gortmaker, J.L. Wiecha \& E.J. Simoes, "School-Based Programs: Lessons Learned from CATCH, Planet Health, and NotOnTobacco," Preventing Chronic Disease (2007), 4(2): 33-37.

${ }^{42}$ C.K. EwALT, "Social action theory for a public health psychology," American Psychologist (1991), 46: 931-946; R. ANDERSEN, Behavioral model of families' use of health services (Research Series № 25) (Chicago, IL: Center for Health Administration Studies, University of Chicago, 1968). 
The theory of social action (K. Ewalt, S. Fitzgerald) is an association of models and psychological principles and public health. ${ }^{43}$ The dominant model in public health - a model of trilateral interaction - between the "master" (client), agent (social worker) and the environment.

While approaches, based on rational choice, are focused only on the client, the theory of social action encourages a socio-contextual analysis of personal change, proposing to evaluate cognitive processes through the influence of social and other environmental factors. The model has three dimensions: self-regulation (preferred core activity), a system of interrelated mechanisms of change, larger environmental systems that contextually determine how personal change mechanisms operate. ${ }^{44}$

The desired state of a person depends on what is needed to achieve goals, such as the impact of social assessment, personal safety, material resources, and proximity. Human habits and health habits are intertwined with other social skills, and how these relationships develop the potential of an individual depends on whether they will promote/hinder their achievement of human goals, or whether will they follow the instructions of the medical workers. For example, the recommended dietary changes for a child with diabetes require that parents regularly purchase products at the store and provide the child with a healthy diet, while preparing two different dishes for the family. That is why health decisions are considered "embedded" in the social network. ${ }^{45}$

The model of behavior based on the use of health care services (L. Gelberg, R. Andersen, V. Leake) emphasizes the use of health care services and the results of health behavior. ${ }^{46}$ This model, launched in medical sociology, considers a broader picture of the impact on health behavior of such an aspect as the health care system. The use of medical services is no longer the end result of the model: it is expanded by "personal health practice" and the new category "behavior of health." The results of health behaviors consist of predictable and diagnosed health and consumer satisfaction with services (R. Andersen, P. Davidson, P. Ganz). ${ }^{47}$

\footnotetext{
${ }^{43}$ R. ANDERSEN, "Revisiting the behavioral model and access to medical care: Does it matter?" Health and Social Behavior (1995), 36: 1-10; C.K. Ewalt, S.T. FitzGerald, "Changing behaviour and promoting well-being after heart attack: A social action theory approach," Irish Journal of Psychology (1995), 15: 219-241; C.K. EwALt, S.T. FitZGERALD, "Changing behaviour and promoting well-being after heart attack: A social action theory approach," 219-241.

${ }^{44}$ C.K. EWALT, "Social action theory for a public health psychology," 932.

${ }^{45}$ Right there, p. 935.

${ }^{46}$ R.M. Andersen, P. Davidson \& P. Ganz, "Symbiotic relationships of quality of life, health services research, and other health research," Quality of Life Research (1994), 3: 365-371.

${ }^{47}$ Right there, p. 396.
} 
The behavior model for the use of health services has a significant empirical evidence (L. Aday, R. Andersen) in the health saving activity of social workers. ${ }^{48}$ Behavioral model for vulnerable groups, as recognized by L. Gelberg and colleagues, is a particularly valuable tool for healthcare social work, because its emphasis is on the use of healthcare services for people in difficult living conditions. Adding a history of life, information about mental health, anamnesis of dependencies, victimology and competing needs to the original model reinforces the effectiveness of the model for working with vulnerable people in longitudinal study, in particular regarding homeless persons. $^{49}$

The transteortical model, justified by K. DiClemente, J. Prochaska, promotes the readiness of individuals to implement the proposed changes in health behavior. ${ }^{50}$ The model shows the way of forming a client's readiness for change and examines the process in successive six necessary steps. Each step characterizes the real state of a person regarding the introduction of changes in health behavior: disinterest, contemplation, reasoning, preparation, activity, maintenance of activity, termination of activity due to completion. ${ }^{51}$ The intrapersonal and social components of health behavior characterize the processes of change in efforts, achieving understanding and changing behavior to a healthy one. These processes are characterized by increased self-awareness, the use of auxiliary means - dramatization of the situation, the use of helping relationships. Changes are obvious if they are implemented continuously and consistently, do not stop and not get stuck at one point at a certain time. This concept gives a social worker the opportunity to intervene in the process of changing behavior in order to clarify the situation "Where is the client now?" ( which of the steps of changes), to understand the situation of the client in the context of a larger social environment and the dynamics of the change process. Clinical studies have confirmed the ef-

${ }^{48}$ L.A. AdAy, R.M. AnderSEn, "A framework for the study of access to medical care," Health Services Research (1974), 9: 208-220 (p. 211).

${ }^{49}$ L. Gelberg, R.M. Andersen \& B.D. LEAKE, "The behavioral model for vulnerable populations: Application to medical care use and outcomes for homeless people," Health Services Research (2000), 34: 1273-1302.

${ }^{50}$ C.C. DiClemente, J.O. Prochaska, "Self change and therapy change of smoking behavior. A comparison of processes of change in cessation and maintenance," Addictive Behavior (1982), 7: 133-142; J.O. ProchasKA, Systems of psychotherapy: A transtheoretical analysis (2nd ed.) (Pacific Grove, CA: Brooks-Cole, 1984), 12-15.

${ }^{51}$ J.O. Prochaska, C.A. Redding \& K.E. Evers, "The transtheoretical model and stages of change.” In K. GLANZ, \& B.K. Rimer, \& K. ViswanATH (Eds.), Health behavior and health education: Theory research and practice (pp. 21-40) (San Francisco, CA: Jossey-Bass, 2008), 27-30. 
fectiveness of joint care compared with traditional medical care in treatment of mental disorders significantly increased (W. Donohue, N. Cummings, J. Cummings). ${ }^{52}$

Other theoretical constructs used in long-term care are: the model of social learning (A. Bandura), the theory of self-management (P. Desi), the model of four quadrants (K. Evers, J. Prochaska, J. Johnson, L. Mauriello, J. Padula, J. Prochaska). ${ }^{53}$ The basis of care organization is a human centered approach with a holistic vision of the person and personally-centered help services that meet the individual needs, needs and values of the patient, which ensure the patients' preferences in the direction of all clinical decisions (A. Relandeau, N. Cherubini, C. Sevet, A. Lafreniere, 2010).$^{54}$

The scientist P. Malcolm argues that health problems, like healthcare system, are related to the effectiveness of community-based services today, it requires teamwork in providing health care services, as well as agreeing it with social networks of patients, since participants in both structures are social support resources. ${ }^{55} \mathrm{M}$. Payne called such a team an open working team or a combination of the concept of a traditional multiprofessional team with the concept of networks. ${ }^{56}$ In general, the main approach that determines the quality of social services provided by a healthcare social worker, is the holistic approach in understanding the person and his health. ${ }^{57}$

\section{CONCLUSIONS}

The theoretical principles of health-caring activity in social work in the United States are represented by eclectic knowledge in connection with the interdisciplinary nature of the industry, based on the integration of authentic

52 W.T. Donohue, N.A. Cummings \& J.L. Cummings, "The unmet educational agenda in integrated care," Clin Psychol Medical Settings (2009), 16: 94-100 (p. 97).

${ }^{53}$ K.E. Evers, J.O. Prochaska, J.L. Johnson, L.M. Mauriello, J.A. Padula \& J.M. ProCHASKA, "A randomized clinical trial of a population and transtheoretical model-based stressmanagement intervention," Health Psychology (2006), 25(4): 521-529.

54 A. Relandeau, N. Cherubini, C.D. Sevet \& A. Lafreniere, Handicap International (Lyon: Social Services, Livelihood and Education Unit, Technical Resources Division, 2010).

${ }^{55}$ P. MALCOLM, "The politics of case management and social work," International Journal of Social Welfare (2000), 9, 2: 82-91.

${ }^{56}$ M. PAyne, "Being a professional social worker," in J. PARKer \& M. Doel (Eds.), Professional Social Work (London: Learning Matters, 2013), 19-38.

${ }^{57}$ E.F. PAtTerson, "The Philosophy and Physics of Holistic Health Care: Spiritual Healing as a Workable Interpretation,” Advanced Nursing (1998), 27(2): 287-293. 
scientific theories and research with the theories of related sciences. Healthcaring activity in social work is characterized by "double-focus" - an intervention at the same time for changes in the structural (environment) and functional (personality) character. Theories are focused on structural transformations (sociological direction), focused on the person (functional direction) and the complex direction (combining ideas of changing the environment and the individual), belong to the basic. Adopted theories of healthcaring activities in social work come from psychology, psychiatry, bioethics, nursing care, health care, sociology, administration. The most commonly used theories of health behavior (model of belief in health, theory of deliberate actions, planned behavior) and theories based on social networks (social behavior, behavior in the use of medical services), the transtheoretical model. The peculiarity of their own theories of social work in the health care is based on the results of practice (evidence based).

\section{REFERENCES}

Abramson, L.Y., Seligman, M.E.P., \& Teasdale, J.D. "Learned helplessness in humans: Critique and reformulation." Journal of Abnormal Psychology (1978), 87: 49-74.

ADAy, L.A., ANDERSEN, R.M. "A framework for the study of access to medical care." Health Services Research (1974), 9: 208-220.

AJZEN, I., \& MADDEN, T.J. "Prediction of goaloriented behavior: Attitudes, intentions, and perceived behavioral control." Journal of Experimental Social Psychology (1986), 22: 453-474.

AJzEN, I. "The theory of planned behavior." Organizational Behavior and Human Decision Processes (1991), 50: 179-211.

Albarracín, D., Johnson, B.T., Fishbein, M., \& Muellerleile, P.A. "Theories of reasoned action and planned behavior as models of condom use: A meta-analysis." Psychological Bulle$\operatorname{tin}$ (2001), 127: 142-161.

ANDERSEN, R. Behavioral model of families' use of health services (Research Series № 25). Chicago, IL: Center for Health Administration Studies, University of Chicago, 1968.

Andersen, R.M., DAVidson, P., \& GANZ, P. "Symbiotic relationships of quality of life, health services research, and other health research." Quality of Life Research (1994), 3: 365-371.

ANDERSEN, R. "Revisiting the behavioral model and access to medical care: Does it matter?" Health and Social Behavior (1995), 36: 1-10.

Becker, M.H., Maiman, L.A., Kirscht, J.P., Haefner, D.P., \& Drachman, R.H. "The health belief model and prediction of dietary compliance: A field experiment." Journal of Health and Social Behavior (1977), 18: 348-366.

Cowles, L.A. Social Work in the Health Field. A Care Perspective (2nd ed.). New York-London-Oxford, 2003.

DeBonis, J.A. The Role of Social Work in Integrated Health. California: California State University Northridge, 2013. 
DiClemente, C.C., Prochaska, J.O. "Self change and therapy change of smoking behavior. A comparison of processes of change in cessation and maintenance." Addictive Behavior (1982), 7: $133-142$.

Donohue, W.T., Cummings, N.A., \& Cummings, J.L. "The unmet educational agenda in integrated care." Clin Psychol Medical Settings (2009), 16: 94-100.

Edwards, H.E., Nash, R.E., Najman, J.M., Yates, P.M., Fentiman, B.J., Dewar, A., SKERMAN, H.M. "Determinants of nurses' intention to administer opioids for pain relief." Nursing Health Science (2001), 3: 149-159.

Evers, K.E., Prochaska, J.O., Johnson, J.L., Mauriello, L.M., Padula, J.A., \& Prochaska, J.M. "A randomized clinical trial of a population and transtheoretical model-based stressmanagement intervention." Health Psychology (2006), 25(4): 521-529.

Ewalt, C.K., FitzGerald, S.T. "Changing behaviour and promoting well-being after heart attack: A social action theory approach.” Irish Journal of Psychology (1995), 15: 219-241.

EWALT, C.K. "Social action theory for a public health psychology." American Psychologist (1991), 46: 931-946.

FishbeIn, M., AJZEN, I. Belief, attitude, intention, and behavior: An introduction to theory and research. Reading, MA: Addison-Wesley, 1975.

FishbeIN, M. "Attitude and the prediction of behavior." In M. FiSHBEIN (Ed.), Readings in attitude theory and measurement (pp. 477-492). New York, NY: Wiley, 1967.

Franks, A., Kelder, S.H., Dino, G.A., Horn, K.A., Gortmaker, S.L., Wiecha, J.L., \& Simoes, E.J. "School-Based Programs: Lessons Learned from CATCH, Planet Health, and Not-On Tobacco." Preventing Chronic Disease (2007), 4(2): 33.

Gehlert, S., Browne, T. Handbook of Health Social Work (2nd ed.). New Jersey: John Wiley \& Sons, 2012.

Gelberg, L., Andersen, R.M., \& LeAke, B.D. "The behavioral model for vulnerable populations: Application to medical care use and outcomes for homeless people." Health Services Research (2000), 34: 1273-1302.

GlanZ, K., Rimer, B.K., \& ViswanAth, K. "Theory, research, and practice in health education." In K. GlanZ, B.K. Rimer, \& K. Viswanath (Eds.), Health behavior and health education: Theory research and practice (pp. 21-40). San Francisco, CA: Jossey-Bass, 2008.

Global definition of the social work profession (2014). URL: http://www.iassw-aiets.org/uploads/ file/20140303_IASSW\%20Website-SW\%20DEFINITION\%20approved\%20IASSW\%20Board\% 2021\% 20Jan\%202014.pdf.

Gochman, D.S. Handbook of Health Behavior Research, I: Personal and Social Determinants. New York: Plenum Press, 1997.

Goncharenko, S. Ukrainian Pedagogical Dictionary. Kyiv: "Lybid”, 1997.

Hochbaum, G. Public Participation in Medical Screening Programs: A Sociopsychological Study. Washington: Public Health Service Publication, 1958.

Ingledue, K., Cottrell, R., \& Bernard, A. “College women's knowledge, perceptions, and preventive behaviors regarding human papillomavirus infection and cervical cancer." American Journal of Health Studies (2004), 19: 28-34.

JANZ, N., BECKER, M. "The health belief model: A decade later." Health Education Quarterly (1984), 11: 1-47. 
Jеммотт, J.B., III, Jемmotт, L.S., \& FonG, G.T. "Reductions in HIV risk-associated sexual behaviors among Black male adolescents: Effects of an AIDS prevention intervention." American Journal of Public Health (1992), 82: 372-377.

Jemmotт, J.B., III, Jemmotт, L.S., Hines, P.M., \& FonG, G.T. "The theory of planned behavior as a model of intentions for fighting among African American and Latino adolescents." Journal of Maternal and Child Health (2001), 5: 253-263.

Kelly, G.R., MAMON, J.A., \& ScOtT, J.E. "Utility of the health belief model in examining medication compliance among psychiatric outpatients." Social Science and Medicine (1987), 11: $1205-1211$.

Kerlinger, F.N. Foundations of behavioral research. New York, NY: Holt, Rinehart and Winston, 1986.

Larson, E.B., Bergman, J., Heidrich, F., Alvin, B.L., \& SchneEweiss, R. "Do postcard reminders improve influenza vaccination compliance?” Medical Care (1982), 20: 639-648.

Luepker, R.V., Perry, C.L., McKinlay, S.M., Nader, P.R., Parcel, G.S., Stone, E.J., Webber, L.S., Wu, M. "Outcomes of a Trial to Improve Children's Dietary Patterns and Physical Activity: The Child and Adolescent Trial for Cardiovascular Health (CATCH)." Journal of the American Medical Association (1996), 275: 768-776.

Malcolm, P. "The politics of case management and social work." International Journal of Social Welfare (2000), 9, 2: 82-91.

MCLeOD, S. (2008). Case Study method. URL: http://www. simplypsychology.org/case-study.html.

PANOS, P. \& PANOS, A. "A model for culture-sensitive assessment of patients in health care settings." Social Work in Health Care (2000), 31(1): 49-62.

PAyne, M. "Being a professional social worker." In PArker, J. \& Doel, M. (Eds.) Professional Social Work (pp. 19-38). London: Learning Matters, 2013.

Patterson, E.F. "The Philosophy and Physics of Holistic Health Care: Spiritual Healing as a Workable Interpretation." Advanced Nursing (1998), 27(2): 287-93.

Perlman, H.H. Social casework: A problem-solving process. Chicago, IL: University of Chicago Press, 1957.

Peterson, C., Bettes, B.A., \& Seligman, M.E.P. "Depressive symptoms and unprompted causal attributions: Content analysis." Behaviour Research and Therapy (1985), 23: 379-382.

ProchasKa, J.O. Systems of psychotherapy: A transtheoretical analysis (2nd ed.). Pacific Grove, CA: Brooks-Cole, 1984.

Prochaska, J.O., Redding, C.A., \& Evers, K.E. "The transtheoretical model and stages of change.” In K. Glanz, \& B.K. Rimer, \& K. Viswanath (Eds.), Health behavior and health education: Theory research and practice (pp. 21-40). San Francisco, CA: Jossey-Bass, 2008.

Relandeau, A., Cherubini, N., Sevet, C.D., \& Lafreniere, A. Handicap International. Lyon: Social Services, Livelihood and Education Unit, Technical Resources Division, 2010.

Rengasamy, S. Social Case Work: Celebrating the dignity and worth of every individual. Compiled by S. Rengasamy Madurai Institute of Social Sciences, 2010.

Rengasamy, S. The puls of Social Work: Theories of Social Work. Alagar Koil Road: Madurai Institute of Social Work, 2015.

Rosenstock, I.M. "What research in motivation suggests for public health." American Journal of Public Health (1960), 50: 295-301. 
Rosenstock, I.M. "Historical origins of the health belief model." Health Education Monographs (1974), 2: 328-335.

Sejwacz, D., Ajzen, I., \& Fishbein, M. "Predicting and understanding weight loss." In I. AJZEN \& M. FISHBEIN (Eds.), Understanding attitudes and predicting behavior (pp. 102-112). Englewood Cliffs, NJ: Prentice-Hall, 1980.

SmetanA, J., \& AdLER, M. "Understanding the abortion decision: A test of Fishbein's value expectancy model.” Journal of Population (1986), 2: 338-357.

TANNER-SMith, E.E., BRown, T.N. "Evaluating the health belief model: A critical review of studies predicting mammographic and pap screening." Social Theory \& Health (2010), 8(1): 95-125.

Van de Water, H.P.A., Boshuizen, H.C., \& Perenboom, R.J.M. "Health expectancy in the Netherlands 1983-1990." European Journal of Public Health (1996), 6: 21-28.

World Summit on Social Development. (1995). Declaration and Programme of Action of the World Summit for Social development. URL: http://www. unesco.org /education/pdf/COPEN HAG.PDF

\section{TEORETYCZNE PODSTAWY PRAKTYK I SZKOLEŃ ZAWODOWYCH PRACOWNIKÓW SOCJALNYCH ZATRUDNIONYCH W SYSTEMIE OPIEKI ZDROWOTNEJ: PRZEGLĄD RETROSPEKTYWNY}

\section{STRESZCZENIE}

Wstęp. Międzynarodowe doświadczenia w zakresie pracy socjalnej w sektorze opieki zdrowotnej pokazują, że czynności wykonywane przez pracownika socjalnego wywierają znaczący wpływ na zdrowie obywateli i są konieczne dla poprawy dobrostanu społeczeństwa.

Cel. Celem badań było przeanalizowanie zaawansowanych rozwiązań teoretycznych opracowanych za granicą, dotyczących szkolenia pracowników socjalnych służby zdrowia pod kątem zastosowania ich na Ukrainie.

Materiały i metody. Wybrano, usystematyzowano i przeanalizowano 53 opracowania naukowe i naukowo-praktyczne dotyczące zagadnień filozoficznych, psychologicznych, pedagogicznych, medycznych oraz problemów pracowników socjalnych zatrudnionych w sektorze ochrony zdrowia. Na podstawie porównania i syntezy otrzymanych informacji dokonano ich uogólnienia, a wyniki przedstawiono $\mathrm{w}$ formie wniosków.

Wyniki. Działania pracowników socjalnych zatrudnionych w systemie opieki zdrowotnej bazują na dwóch podstawowych grupach teorii - podstawowych, opierających się na rezultatach działań socjalnych, oraz tych adaptowanych z psychologii, psychiatrii, bioetyki, opieki pielęgniarskiej, opieki zdrowotnej, socjologii i administracji.

Wnioski. W pracy socjalnej w sektorze opieki zdrowotnej najczęściej wykorzystywane są teorie zachowań zdrowotnych (model przekonań zdrowotnych, teoria działań celowych, zachowanie zaplanowane), teorie bazujące na relacjach społecznych (zachowania społeczne, zachowanie w trakcie korzystania z usług medycznych), a także model transteoretyczny. W szkoleniu pracowników socjalnych, zatrudnionych w systemie opieki zdrowotnej, ważne są zarówno teorie podstawowe jak i te adaptowane. W praktyce ważne jest ich wszechstronne zastosowanie, a także wiedza eklektyczna w odniesieniu do interdyscyplinarnego charakteru takiej pracy socjalnej.

Slowa kluczowe: praca socjalna; opieka zdrowotna; teoretyczne podstawy; praktyka; pracownicy socjalni; szkolenia zawodowe. 